\title{
Management of Alternaria Leaf Spot of Blond Psyllium (Plantago ovata Forssk.) Through Plant Extracts and Bio-Agents
}

\author{
Tejpal Bajaya ${ }^{1}$, R.R. Ahir ${ }^{1}$, R.P. Ghasolia ${ }^{1}$, \\ Meera Choudhary ${ }^{1}$ and Mamta Devi Choudhary ${ }^{2 *}$ \\ ${ }^{1}$ Department of Plant Pathology, ${ }^{2}$ Department of Entomology, SKN College of Agriculture \\ (SKNAU) Jobner- 303329, Jaipur, Rajasthan, India \\ *Corresponding author
}

\section{A B S T R A C T}

\begin{tabular}{|c|c|}
\hline $\begin{array}{l}\text { Ke y w o r d s } \\
\text { Blond psyllium, } \\
\text { Isabgol, Alternaria } \\
\text { alternata, Plant } \\
\text { extract, Bio-agent. }\end{array}$ & $\begin{array}{l}\text { Studies were conducted to know the efficacy plant extracts and bio-agents } \\
\text { against Alternaria leaf spot of blond psyllium/isabgol (Plantago ovata } \\
\text { Forssk.) caused by Alternaria alternata which has become an severe } \\
\text { problem in isabgol growing areas of Rajasthan. Among five plant extracts }\end{array}$ \\
\hline Article Info & growth $(74.30 \%)$ as well as in reducing disease intensity $(53.26 \%)$ by \\
\hline $\begin{array}{l}\text { Accepted: } \\
\text { 04 July } 2017 \\
\text { Available Online: } \\
\text { 10 September } 2017\end{array}$ & $\begin{array}{l}\text { applying two sprays at } 7 \text { days interval. Among four bio-agents, } \\
\text { Trichoderma viride was observed highly effective in inhibiting mycelial } \\
\text { growth }(79.20 \%) \text { and in reducing disease intensity }(41.84 \%) \text {. }\end{array}$ \\
\hline
\end{tabular}

\section{Introduction}

Blond psyllium (Plantago ovata Forssk.) also known as "isabgol", is an annual herb with narrow linear rosette like leaves belonging to the family Plantaginaceae. Among 200 species of blond psyllium, Plantago ovata Forssk is known for superior quality of husk. Isabgol seeds and husk is used in medicines especially for relieving constipation. Isabgol is an important cash crop cultivated for its export and being of important medicinal value is reported to have larger demands and is traded in major medicinal drug markets of the world. India commands nearly monopoly in the production and export of the seed and husk to the world market. India is earning about Rs. 1600 million as foreign exchange from the export of blond psyllium products to countries like USA, Germany, France, England, Spain and Belgium (Maiti, 2000). In India, the isabgol crop is mainly grown as commercial crop in Gujarat, Rajasthan and Madhya Pradesh. However, the crop is spreading to other non-traditional parts of the country such as Haryana, Uttar Pradesh and Karnataka. In Rajasthan, it is being cultivated in 304430 hectare area with a total production of 144177 tonnes of seeds with an average productivity of $474 \mathrm{~kg} / \mathrm{ha}$ (Anonymous, 201516). In Rajasthan, isabgol mainly cultivated in Barmer, Jalore, Nagaur, Jodhpur, Pali, Sirohi, Chittorgarh, Udaipur and Jaisalmer districts. Alternaria leaf spot of isabgol (Plantago 
ovata Forssk.) caused by Alternaria alternata, has become a severe problem in Isabgol growing areas of Rajasthan. Shekhawat and Prasad (1971) have tested nine plant extracts against Alternaria alternata, out of them five viz., Allium cepa, A. sativum, Ocimum sanctum, Mentha piperita and Beta vulgaris showed strong inhibitory action. Parveen and Kumar (2004) proved Trichoderma viride as most effective antagonist in inhibiting the mycelial growth of Alternaria triticina.

\section{Material and Methods}

\section{Efficacy of plant extracts (in vitro)}

The effect of plant extracts was tested at two concentrations i.e. 5 and 10 per cent. For preparing plant extracts of plant parts including leaves, rhizomes and cloves to be tested were first washed with tap water followed by sterilized water and then air dried. Plant parts then thoroughly grind separately in grinder using equal amount of sterilized distilled water to get stock solution. The mixture was squeezed with doublelayered sterilized cheese cloth.

The extract thus obtained was considered as of 100 per cent concentration. It was further diluted to get 5 and 10 per cent of concentrations using sterilize distilled water. The effect against mycelial growth was tested using Poisoned Food Technique. Required quantity of each plant extract was mixed thoroughly in sterilized melted PDA aseptically under laminar flow and thoroughly mixed to get desired concentrations; medium amended with desired quantity of plant extract was poured aseptically in sterilized Petri dishes and was allowed to solidify. Each plate was inoculated with $2 \mathrm{~mm}$ disc of mycelial bit taken from the periphery of 10day-old culture A. alternata growing on PDA. The inoculated Petri dishes were then incubated at $25 \pm 1{ }^{\circ} \mathrm{C}$. Four Petri dishes were used for each treatment serving as four replications. Petri dishes without plant extract served as control. Experiment was conducted in Completely Randomized Design (CRD) with four replications. Colony diameter was measured after 7 days of incubation. Per cent growth inhibition was calculated as per formula of Vincent (1947).

Per cent growth inhibition= $=\frac{\text { C-T }}{\text { C }}$

Where,

$\mathrm{C}=$ Diameter of the colony in check (average of both diagonals)

$\mathrm{T}=$ Diameter of the colony in treatment (average of both diagonals)

\section{Efficacy of plant extract (in vivo)}

An experiment was conducted during rabi 2016-17 with local susceptible cultivar of isabgol with four replications. Artificial inoculation was done with spore suspension $\left(1 \times 10^{5}\right.$ spore/ml) of Alternaria alternata and after four days of inoculation of the culture, two sprays $(10 \%)$ of each plant extract was applied at an interval of seven days.

Observations on per cent disease intensity (PDI) was recorded by using 0-5 disease rating scale of Rathore and Pathak (2001) where, $0=$ plant completely free from disease symptoms; $1=20 \%$ leaf area of a plant covered with leaf spot; $2=21-40 \%$ leaf area of a plant covered with leaf spot; $3=41-60 \%$ leaf area of a plant covered with leaf spot; $4=61$ $80 \%$ leaf area of a plant covered with leaf spot; 5=More than $80 \%$ leaf area of a plant covered with leaf spot and per cent disease intensity (PDI) was calculated as per formula given by McKinney (1923) as follows: 
Per cent

$$
\text { Sum of all individual ratings }
$$

Disease intensity $=$ $x 100$

Number of leaves observed $\mathrm{X}$ Maximum disease rating

\section{Efficacy of bio-agent (In vitro)}

Four bio-agents i.e. Trichoderma viride, Trichoderma harzianum, Bacillus subtilis and Pseudomonas fluorescens were evaluated for their antagonistic efficacy against Alternaria alternata by dual culture technique. Twenty $\mathrm{ml}$ of PDA was poured into sterile Petri plates. Fungal bio-agents were evaluated by inoculating the pathogen at one side of the Petri plate and the bio-agent inoculated at exactly opposite side of the same plate by leaving 3-4 cm gap. For this, actively growing cultures were used. In case of bacterial bioagent evaluation, two mycelial discs of pathogen were inoculated and bacterial bioagent was streaked in the center of the plate.

One control was maintained wherein only test fungus was grown. Such treatments replicated four times. The plates were incubated for seven days at $25 \pm 1{ }^{\circ} \mathrm{C}$. After incubation, the colony diameter of Alternaria alternata was recorded. Per cent inhibition was calculated by using the formula of Vincent (1947).

\section{Efficacy of bio-agent (In vivo)}

An experiment was conducted during rabi 2016-17 with local susceptible cultivar of isabgol with four replications. Artificial inoculation was done with spore suspension $\left(1 \times 10^{5}\right.$ spore $\left./ \mathrm{ml}\right)$ of Alternaria alternata and after four days of inoculation of the culture, each bio-agent was sprayed and repeated after seven days of first spray. The observations on disease intensity were recorded after 10 days of last spray.

\section{Result and Discussion}

Five plant extracts i.e. datura (Datura stramonium), garlic (Allium sativum), giloy (Tinospora cordifolia), karanj (Pongamia pinnata) and ginger (Zingiber officinale) were tested at two concentrations viz. 5 and 10 per cent in vitro against Alternaria alternata on PDA by poisoned food techniques. Results of mean analysis (Table 1) revealed that maximum mycelial growth inhibition was observed in garlic clove extract $(62.40 \%)$ followed by datura $(56.25 \%)$, giloy $(44.26 \%)$ and ginger $(40.15 \%)$ and minimum 36.35 per cent in karanj extract. Minimum disease intensity $(30.10 \%)$ was recorded (Table 2 ) in garlic clove extracts with decreased intensity by after applying two foliar sprays. This was followed by datura (32.40\%), giloy $(41.80 \%)$ and ginger (47.26\%). Karanj extract was found least effective as it gave higher intensity $(48.00 \%)$. The results obtained in the present study are in accordance with the results obtained by Barros et al., (1995), Singh and Majumdar (2001), Jadeja and Pipliya (2008), Panchal and Patil (2009) and Bochliya et al., (2012) and Shekhawat and Prasad (1971).

In the present study, four bio-agents were tested in vitro as well as in vivo against $A$. alternata causing Alternaria leaf spot of isabgol. All bio-agents tested reduced mycelial growth and disease intensity of $A$. alternata as compared to control. Among these, $T$. viride was observed to be significantly superior and recorded highest mycelial growth inhibition $(79.20 \%)$ and thereby proved most effective antagonist (Table 3) against the test fungus, followed by T. harzianum $(74.40 \%)$ and Pseudomonas fluorescens (60.40\%). Minimum inhibition was observed with Bacillus subtlis (44.20\%). 
Table.1 Efficacy of plant extracts against Alternaria alternata by poisoned food technique at $25+10 \mathrm{C}$ for 7 days

\begin{tabular}{lccc}
\hline Plant extracts & \multicolumn{3}{c}{$\begin{array}{c}\text { Per cent growth inhibition at different } \\
\text { concentration }\end{array}$} \\
\cline { 2 - 4 } & $\mathbf{5 \%}$ & $\mathbf{1 0 \%}$ & Mean \\
\hline Datura & 47.00 & 65.50 & 56.25 \\
Garlic & $(43.28)$ & $(54.03)$ & \\
& 50.50 & 74.30 & 62.40 \\
Giloy & $(45.29)$ & $(59.54)$ & \\
& 40.12 & 48.40 & 44.26 \\
Karanj & $(39.30)$ & $(44.08)$ & \\
& 30.40 & 42.30 & 36.35 \\
Ginger & $(33.46)$ & $(40.57)$ & 40.15 \\
& 35.20 & 45.10 & \\
Control & $(36.39)$ & $(42.19)$ & - \\
\hline & 0.00 & 0.00 & \\
\hline P & $\mathbf{S E m} \pm$ & $\mathbf{C D}(\mathbf{p}=\mathbf{0 . 0 5 \%})$ & \\
C & 0.62 & 1.73 & \\
P x C & 0.88 & 2.45 & \\
\hline
\end{tabular}

*Average of four replications

Figures given in parentheses are angular transformed values

Table.2 Efficacy of plant extracts against Alternaria alternata of isabgol

\begin{tabular}{|c|c|c|c|}
\hline Treatments & Concentration & $\begin{array}{c}\text { Per cent disease } \\
\text { intensity }\end{array}$ & $\begin{array}{c}\text { Per cent disease } \\
\text { reduction over control }\end{array}$ \\
\hline Datura & 10 & $\begin{array}{c}32.40 \\
(34.70)\end{array}$ & 49.69 \\
\hline Garlic & 10 & $\begin{array}{c}30.10 \\
(33.27)\end{array}$ & 53.26 \\
\hline Giloy & 10 & $\begin{array}{c}41.80 \\
(40.28)\end{array}$ & 35.09 \\
\hline Karanj & 10 & $\begin{array}{c}48.00 \\
(43.85)\end{array}$ & 25.47 \\
\hline Ginger & 10 & $\begin{array}{c}47.26 \\
(43.43)\end{array}$ & 26.61 \\
\hline Control & 0.0 & $\begin{array}{c}64.40 \\
(53.37)\end{array}$ & 0.00 \\
\hline $\begin{array}{l}\text { SEm } \pm \\
\operatorname{CD}(p=0.05)\end{array}$ & & $\begin{array}{l}1.53 \\
4.72\end{array}$ & \\
\hline
\end{tabular}

*Average of four replications

Figures given in parentheses are angular transformed values 
Table.3 Effect of bio-agents against mycelial growth of A. alternata after

7 days of incubation at $25+10 \mathrm{C}$

\begin{tabular}{lc}
\hline Bio-agents & Per cent mycelia growth* inhibition \\
\hline Trichoderma harzianum & 74.40 \\
& $(59.60)$ \\
Trichoderma viride & 79.20 \\
& $(62.87)$ \\
Pseudomonas fluorescens & 60.40 \\
& $(51.00)$ \\
Bacillus subtilis & 44.20 \\
& $(41.67)$ \\
Control & 0.00 \\
\hline SEm+ & 1.84 \\
CD $(\mathbf{p}=\mathbf{0 . 0 5})$ & 5.12 \\
\hline
\end{tabular}

* Average of four replication

Figures given in parentheses are angular transformed value

Table.4 Efficacy of bio-control agents against Alternaria alternata of isabgol

\begin{tabular}{|c|c|c|c|}
\hline Bio-agents & Dose (g/lit) & $\begin{array}{c}\text { Per cent disease } \\
\text { intensity }\end{array}$ & $\begin{array}{l}\text { Per cent disease } \\
\text { reduction over control }\end{array}$ \\
\hline Trichoderma harzianum & 4 & $\begin{array}{c}36.50 \\
(37.17)\end{array}$ & 39.69 \\
\hline Trichoderma viride & 4 & $\begin{array}{l}35.20 \\
(36.39)\end{array}$ & 41.84 \\
\hline Pseudomonas fluorescens & 6 & $\begin{array}{c}39.50 \\
(38.94)\end{array}$ & 34.73 \\
\hline Bacillus subtilis & 6 & $\begin{array}{c}45.90 \\
(42.65)\end{array}$ & 24.16 \\
\hline Control & 0.00 & $\begin{array}{c}60.52 \\
(51.07)\end{array}$ & 0.00 \\
\hline $\begin{array}{l}\text { SEm+ } \\
\text { CD }(p=0.05)\end{array}$ & & $\begin{array}{l}0.96 \\
2.95\end{array}$ & \\
\hline
\end{tabular}

* Average of four replication

Figures given in parentheses are angular transformed value

Foliar sprays of bio-agents indicated that minimum disease intensity $(35.20 \%)$ was recorded (Table 4) with $T$. viride and it was significantly superior over control followed by $T$. harzianum $(36.50 \%)$. In case of bacterial bio-agents, Pseudomonas fluorescens was observed to be effective in decreasing $(39.50 \%)$ disease intensity as compared to Bacillus subtilis (45.90\%). Kumar (2004) have reported the effectiveness of Trichoderma viride in inhibiting the mycelial growth of Alternaria triticina causing leaf blight of wheat in vitro. Jadeja and Pipliya (2008) have also been proved $T$. harzianum and T. viride as most effective antagonist by recording 100 per cent inhibition of A. burnsii, the causal organism of blight of cumin. Deepak et al., (2008) have also been recorded maximum reduction with T. harzianum under in vitro and field 
conditions against $A$. burnsii. The results are also in close agreement with the findings of Bochalya et al., (2012) who reported that $T$. viride was most superior against Alternaria alternata over other treatment in vitro conditions.

\section{References}

Anonymous, 2014-2015. Directorate of Horticulture (Statistics) 3137 Laguna Street Jaipur, Rajasthan.

Barros, S.T., Deoliveria, N.T. and Mala, L.C. 1995. Effect of the garlic (Allium sativum) bulb extracts on mycelia growth and spore germination of Curvularia sp. and Alternaria sp. Summa Phytopathologica, 21: 168-170.

Bochalya, M. S., Shekhawat, K. S., Kumar, A., Singh, R. and Chohan, P. K. 2012. Management of Alternaria alternata causing Alternaria fruit rot of brinjal (Solanum melongena) under in vitro condition. Biopesticides Inter. 8 (2): 131-137.

Jadeja, K.B., and Pipliya, B.H. 2008. In vitro evaluation of plant extracts and bioagents against Alternaria burnsii Uppal, Patel \& Kamat causing blight of cumin (Cuminum cyminum L.) J. Spices Aromatic Crops, 17 (1): 26-28.

Maiti, S., 2000. Cultivation of isabgol (Plantago ovata Forssk). Bulletin: National Research Centre for Medicinal and Aromatic Plants. Boriavi, Anand, Gujarat. pp. 1.
McKinney, H. H., 1923. A new system of grading plant diseases. Agriculture Research, 26: 95-98.

Panchal, D.G., and Patil, R.K. 2009. Ecofriendly approach for management of fruit root of tomato caused by Alternaria alternata. J. Mycol. Pl. Pathol. 39 (1): 66-69.

Parveen, S., and Kumar, V.R. 2004. Antagonism by Trichoderma viride against leaf blight pathogen of wheat. $J$. Mycol. Pl. Pathol. 34: 220-222.

Parveen, S., and Kumar, V.R. 2004. Antagonism by Trichoderma viride against leaf blight pathogen of wheat. $J$. Mycol. Pl. Pathol. 34: 220-222.

Rathore, B. S., and Pathak, V. N. 2001. Management of downy mildew of blond psyllium through seed treatment-cumfoliar sprays. Indian Phytopath, 54: 465468.

Shekhawat, P.S., and Prasad, R. 1971. Antifungal properties of some plant extracts, in inhibition of spore germination. Indian Phytopathol. 24: 800-802.

Singh, J., and Majumdar, V.L. 2001. Efficacy of plant extracts against Alternaria alternata the incitant of fruit rot of pomegranate (Punica granatum L.). J. Mycol. Pl. Path., 31: 346-349.

Vincent, J.M., 1947. Distortions of fungal hyphae in the presence of certain inhibitors. Nature, 150: 850.

\section{How to cite this article:}

Tejpal Bajaya, R.R. Ahir, R.P. Ghasolia, Meera Choudhary and Mamta Devi Choudhary. 2017. Management of Alternaria Leaf Spot of Blond psyllium (Plantago ovata Forssk.) Through Plant Extracts and Bio-Agents. Int.J.Curr.Microbiol.App.Sci. 6(9): 241-246. doi: https://doi.org/10.20546/ijcmas.2017.609.032 